Article

\title{
Fluorescence Excitation-Emission Spectroscopy: An Analytical Technique to Monitor Drugs of Addiction in Wastewater
}

\author{
Meena K. Yadav ${ }^{1, *(D)}$, Rupak Aryal ${ }^{2}(\mathbb{D})$, Michael D. Short ${ }^{3}(\mathbb{D}$ and Christopher P. Saint $1,3,4, *(\mathbb{D})$ \\ 1 Natural and Built Environments Research Centre, University of South Australia, Mawson Lakes, \\ SA 5095, Australia \\ 2 Center for Water Technology in Water and Wastewater, University of Technology, Sydney, NSW 2007, \\ Australia; rupak.aryal@uts.edu.au \\ 3 Future Industries Institute, University of South Australia, Mawson Lakes, SA 5095, Australia; \\ michael.short@unisa.edu.au \\ 4 Division of Information Technology, Engineering and the Environment, University of South Australia, \\ Mawson Lakes, SA 5095, Australia \\ * Correspondence: meena.yadav@mymail.unisa.edu.au (M.K.Y.); christopher.saint@unisa.edu.au (C.P.S.); \\ Tel.: +61-8-830-21682 (M.K.Y.); +61-8-830-25071 (C.P.S.)
}

Received: 5 February 2019; Accepted: 18 February 2019; Published: 22 February 2019

\begin{abstract}
Emerging contaminants of concern have become a serious issue for the scientific community and society more broadly in recent years due to their increasingly widespread environmental distribution and largely unknown environmental and human health impacts. This study aimed to explore the use of fluorescence excitation-emission (F-EEM) spectroscopy as an alternative analytical method to evaluate the presence of key drugs of addiction (benzoylecgonine, methamphetamine, MDMA, codeine and morphine) in wastewater treatment plants. The chemicals of interest from wastewater were extracted by mixed-mode solid phase extraction and quantified using liquid chromatography tandem mass spectrometry. The same wastewater samples were also analysed by a fluorescence spectrophotometer for fluorescence spectra at wavelengths $280-600 \mathrm{~nm}$ (emission) and 200-600 nm (excitation). The study also investigated the relevance of different methods for interpreting F-EEM matrices data including parallel factor analysis (PARAFAC) modelling and fluorescence regional integration technique. PARAFAC identified four components, and among them, component $C 2$, identified at the $\lambda \mathrm{ex} / \lambda \mathrm{em}=275 / 340 \mathrm{~nm}$ wavelength associated with proteinaceous compounds most likely related to tryptophan amino acid, showed significant correlation with codeine removal. MDMA and morphine were not correlated to any of the fluorescence regions. The fluorescence regions related to aromatic protein-like fluorescence were correlated significantly with drug concentration and so may offer a suitable alternative approach for monitoring drugs including benzoylecgonine, methamphetamine and codeine.
\end{abstract}

Keywords: codeine; EEM spectroscopy; fluorescence spectroscopy; methamphetamine; PARAFAC modelling; removal efficiency

\section{Introduction}

There is an exponential increase in the usage of drugs of addiction (DOA) that has led to concomitant increases of these compounds in different environmental systems, including wastewater, recycled water, surface water, groundwater and even drinking water [1-3]. Yadav, et al. [4] reported that the production, synthesis and usage of DOA are increasing at an unprecedented pace globally and at a rate above that of normal global population growth. Wastewater effluents are recognised as 
the primary source for the transfer of DOA into the environment or used in recycling schemes $[5,6]$, and frequent monitoring of these compounds is the only means of assessing their removal efficiency during treatment and residue levels in discharged water (effluent).

The analytical methods currently used for detection and quantification of DOA are expensive, time-consuming, difficult to use and require high-level training and guidance. Thus, a simple, rapid and cost-effective alternative method would be beneficial to a wide range of stakeholders. Amongst several techniques under consideration, fluorescence spectroscopy is a potential tool since it has shown promising results over a wide range of analytes $[7,8]$. This technique is highly sensitive and can be used to characterize organic matter in water sources through three-dimensional spectra called excitation-emission matrices (EEM) [9]. There are several methods to interpret complex EEM data, such as parallel factor analysis (PARAFAC) in which the data is mathematically decomposed into chemically independent components determining both qualitative and quantitative analysis $[10,11]$ and fluorescence regional integration (FRI), where EEM data is divided into a number of regions, each representing a group of substances of similar characteristics [12].

This study aimed to determine possible relations between the compounds of interest and fluorophore components that can best describe the compounds of interest. To our knowledge, this work is the first of its type that presented the relationship between these drugs and the nature of organic chemicals present in wastewater identified/quantified by fluorescence spectra using PARAFAC and FRI. The outcome shows that the fluorescence method could be used to monitor some of these emerging contaminants on a regular basis as an alternative to more complex analytical methods.

\section{Materials and Methods}

\subsection{Sample Collection and Preparation}

Twenty-four hour composite wastewater samples (influent and effluent) were collected for seven consecutive days on alternative months from June to December 2016 from four Australian Wastewater Treatment Plants (WWTPs). Each WWTP was operated with different secondary treatment processes, and detailed characteristics of each WWTP is presented in Table S1. The samples were preserved at $4{ }^{\circ} \mathrm{C}$, and analysis was performed within $48 \mathrm{~h}$.

\subsection{Analytical Methods}

The DOA chosen for this study, based on recorded concentrations from our previous work [13], were: cocaine in the form of its major metabolite benzoylecgonine (BE); methamphetamine (METH); 3-4-methylenedioxymethamphetamine (MDMA); codeine; and morphine. These compounds were extracted by solid phase extraction (SPE) and analysed using liquid chromatography-tandem mass spectrometry (LC-MS/MS) according to published methods [14].

For dissolved organic carbon (DOC), UV-Vis absorbance, and fluorescence spectral analysis, the samples were filtered using $0.45 \mu \mathrm{m}$ pre-rinsed sterile cellulose membrane filters the same day and analysed within $48 \mathrm{~h}$. DOC was determined by the non-purgeable organic carbon (NPOC) method using a Sievers TOC analyser (Sievers InnovOX, GE Analytical Instruments, USA) attached to an autosampler. UV-Vis absorbance was measured by spectrophotometer (UV 340, MIOSTECH, China) at 200-700 nm wavelength at $1 \mathrm{~nm}$ interval in medium scanning mode. Fluorescence EEM spectra were acquired by a Perkin Elmer LS55 fluorescence spectrophotometer (United Kingdom) using $1 \mathrm{~cm}$ quartz cuvette at wavelengths of 280-600 nm emission (Em) and 200-600 nm excitation (Ex) at $7 \mathrm{~nm}$ slit widths. F-EEM spectroscopic method generates three-dimensional spectra where fluorescence intensities are scanned for wide-ranging excitation and emission wavelengths (Figure 1). The samples were pre-diluted with Milli-Q water to minimize the inner-filter effect [9]. 


\subsection{Fluorescence Excitation-Emission Matrix Data Analysis}

F-EEM data were analysed by two methods: i) PARAFAC and ii) FRI. PARAFAC was performed using drEEM toolbox through MATLAB R2015b, as defined by Andersson and Bro [15]. The raw EEM data were pre-processed including spectral and inner filter corrections, Raman normalization and blank subtraction, as described by Murphy, et al. [11], prior to PARAFAC modelling. The PARAFAC modelling was used to decompose the data sets into diverse fluorescent components applying non-negativity constraints using alternating least square solution. Four fluorophore component models were validated after split-half validation method and $F_{\max }$ intensities of each sample was obtained, which was used as a specific fluorescence index.

The FRI method suggested by Chen, et al. [12] was used to calculate five regions: protein 1 (P1), protein 2 (P2), fulvic-acid like (FA), humic-acid like (HA) and soluble microbial by-products (SMP).

\subsection{Statistical Analysis}

Statistical analyses were performed using IBM SPSS Statistics, Version 23.0. (Armonk, NY: IBM Corp.). Relationships between F-EEM regions (PARAFAC components and FRI regions) were investigated using Bivariate Pearson correlation (alpha significance $\leq 0.05$ at $95 \%$ confidence interval) with a two-tailed test of significance.

\section{Results and Discussion}

\subsection{Fluorescence-EEM}

F-EEM spectra obtained from fluorescence spectroscopy can provide a qualitative assessment of the performance of the treatment plant regarding organics removal, but lacks quantitative evaluation. Figure S1 compares the influent and effluent F-EEM's of WWTP1 and WWTP4 operated with a conventional activated sludge reactor (ASR) and integrated fixed-film ASR secondary treatment, respectively. A significant decolourization effect in the EEM spectra of WWTP4 effluent relative to WWTP1 indicates better removal of the fluorescent organic matter by WWTP4 which is in agreement with the higher DOC removals recorded by that plant (see Table S2 for DOC data). Although the EEM spectra provide useful information, it is only semi-quantitative; thus, fluorescent regions were evaluated by PARAFAC modelling and FRI method, as per Section 2.3, to provide a quantitative assessment. The PARAFAC analysis identified four fluorophore components through a split-half validation method for wastewater samples, as presented in Figure 1. Each component had a single peak with single excitation and emission maxima, as reported in Table 1.

Table 1. Peaks identified from parallel factor analysis (PARAFAC)-derived components and compared with other studies.

\begin{tabular}{ccccc}
\hline Components & Peak Identified * & $\begin{array}{c}\text { Maximum Ex/Em } \\
(\mathbf{n m})\end{array}$ & $\begin{array}{c}\text { Existing substances } \\
\text { in the samples }\end{array}$ & $\begin{array}{c}\text { Previously reported } \\
\text { by References }\end{array}$ \\
\hline C1 & $\mathrm{A}^{*}$ & $250 / 460$ & Humic-like: Terrestrial & {$[16-18]$} \\
$\mathrm{C} 2$ & $\mathrm{~T}^{*}$ & $275 / 340$ & Protein-like: Tryptophan & {$[19-21]$} \\
$\mathrm{C} 3$ & $\mathrm{C}^{*}$ & $345 / 420-440$ & Wastewater: Fulvic acid-like & {$[22,23]$} \\
$\mathrm{C} 4$ & $\mathrm{M}^{*}$ & $310 / 400$ & Humic-like: Microbial & {$[24,25]$} \\
\hline
\end{tabular}

* According to Coble [26].

Figure 1 shows the corresponding EEM contour plots and line plots presenting spectral loadings for each component. According to the emission and excitation peaks, $\mathrm{C} 1$ was identified as a humic-like component traditionally named peak A, C2 as proteinaceous component most likely related to tryptophan amino acid, component $\mathrm{C} 3$ as fulvic-acid like and $\mathrm{C} 4$ as a humic-like microbial component. The component $\mathrm{C} 1(\lambda \mathrm{ex} / \lambda \mathrm{em} 250 / 460)$ dominated in almost all effluent samples, and the peak identified represents terrestrial humic-like organics known to be present in wastewater-impacted 
environments [22]. The protein-like region, component C2 $(\lambda \mathrm{ex} / \lambda \mathrm{em} \sim 275 / 340)$, was dominant in influent samples, and a clear decline was observed in effluents across WWTPs. The component C2, also known as Peak T, generally contributes the highest intensity peak in wastewater. This component was mostly related to different biological activities, including bacterial [20], and thus preferential decline is expected during the treatment process. Component $C 3(\lambda \mathrm{ex} / \lambda \mathrm{em} \sim 345 / 420-440)$ peaks are associated with a fulvic acid-like fluorophore (peak C) that characterises wastewater and was detected at reduced intensity in the effluent. Our component $\mathrm{C} 3$ is similar to a component (C2) described by Yamashita, et al. [16] that resembles the humic-like fluorophore. Mostofa, et al. [27] observed a similar peak in their study and identified this as a household detergent-like component. Finally, the $\mathrm{C} 4$ region ( $\lambda$ ex/ $/$ em 310/400) is designated as a humic-like fluorophore that signifies microbial contamination (peak M; Coble [26]). Goslan, et al. [25] recognised a similar peak in their study for carboxylic acid representing a nitrogen-containing compound. Accordingly, its intensity was reduced here in effluent samples as compared to influent samples.

A Pearson correlation coefficient was computed to assess the relationship between DOC concentrations and PARAFAC components. Overall, a significant correlation was identified between DOC concentration and $\mathrm{C} 1(\mathrm{p}=0.027)$ and $\mathrm{C} 4(\mathrm{p}=0.005)$ components for $\mathrm{F}_{\max }$ intensities of effluent samples. This observation suggests that an increase in DOC was possibly due to increased humic substances [28] as component C1 and C4 are identified to consist of humic-like substances.
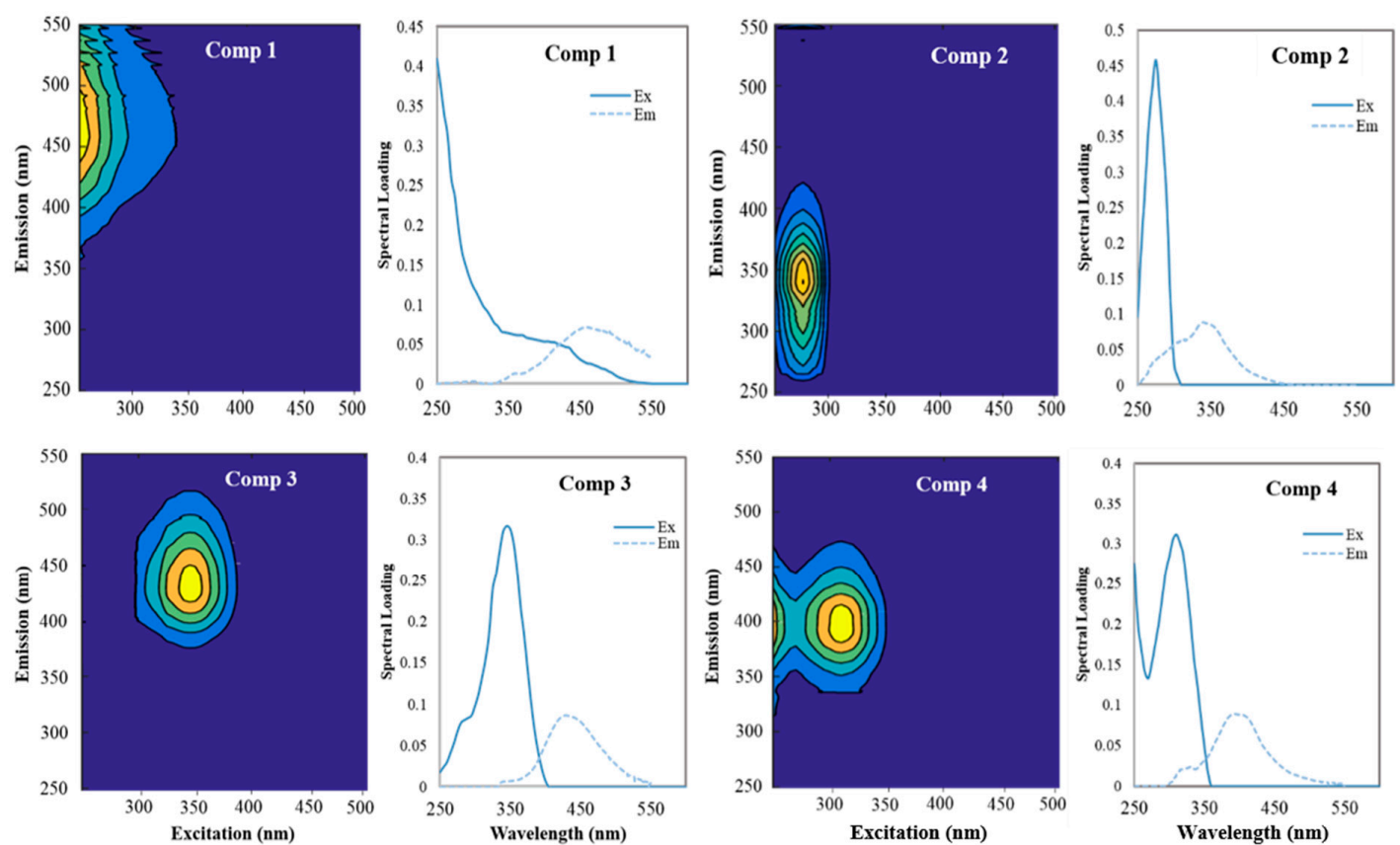

Figure 1. Contour plots of the four components derived from the excitation-emission matrices (EEM) dataset after PARAFAC analysis (Left), and line plots showing spectral loadings on four components (Right). The relative abundances of five regions identified based on the method of Chen, et al. [12] are summarised in Figure 2. The results showed higher percentages of protein compounds (P1, P2 and $\mathrm{SMP}$ ) as compared to organic compounds (HA and FA), and these findings are comparable to others that supported a higher proportion of proteins in wastewater $[29,30]$. 


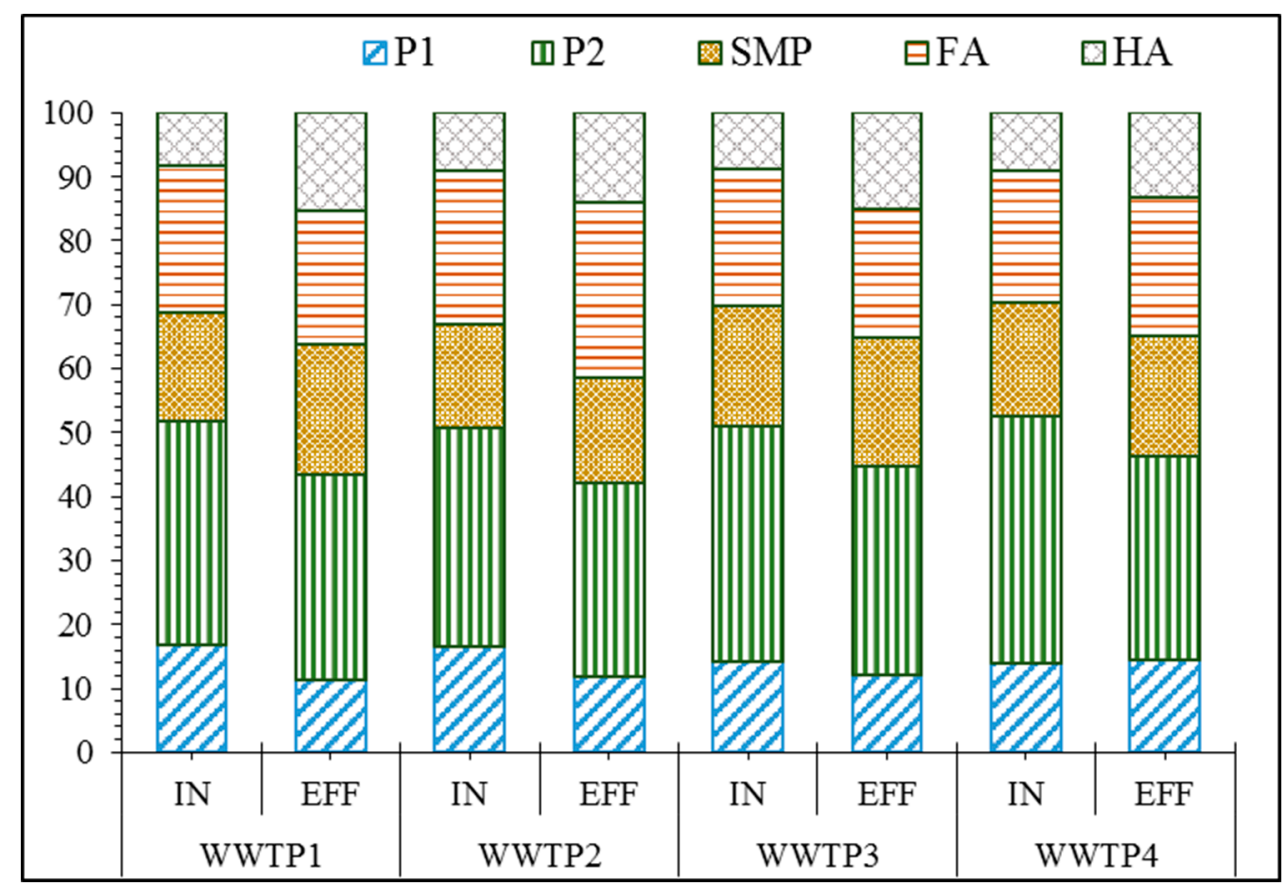

Figure 2. The average abundance percentages of five identified regions in influent and effluent wastewater samples across all four study wastewater treatment plants (WWTPs). P1 and P2 refers to aromatic protein; FA: Fulvic Acid-like; SMP: Soluble Microbial by-product-like; HA: Humic Acid-like.

\subsection{Fluorescence-EEM Removal during Treatment Processes}

The removal efficiency of each WWTP for an individual component is illustrated in Figure 3. For each WWTP, $\mathrm{F}_{\max }$ intensities with respect to four components were recognised as 'H-Terres' (humic-like: terrestrial C1), 'P-Tryp' (protein tryptophan-like C2), 'FA' (fulvic acid-like C3) and 'H-Microbial' (microbial humic $\mathrm{C} 4$ ). Overall, the $\mathrm{C} 2$ proteinaceous component was reduced most efficiently during wastewater treatment among all WWTPs, especially by WWTP3b (membrane bioreactor followed by UV disinfectant).

The results of Pearson correlation analysis between identified PARAFAC components $(n=4)$ and FRI regions $(n=5)$ are shown in Table 2. A positive relationship was identified between component $C 4$ and other components C1, C2 and C3 ( $p=0.001)$ because C4 was linked with carboxylic acid, and other components C1 (HA) and C3 (FA) may contain carboxylic groups in their structure. Similarly, C1 and C3 are very well correlated since both humic and fulvic acids have similar structure and likely have similar methods for removal from investigated WWTPs. On the other hand, a negative significant relationship was confirmed between $\mathrm{P} 1-\mathrm{C} 1(p=0.04)$ and $\mathrm{P} 1-\mathrm{C} 3(p=0.002)$ components. P1 is related to proteinaceous compounds. The increase of microbial activity during activated sludge treatment may have helped to degrade $\mathrm{C} 1$ and C3, and while doing so, may have left a microbial footprint of P1 protein compounds. Yu, et al. [31] describe how operational conditions such as sludge retention time (SRT) can affect the characteristics of SMPs in activated sludge WWTP. For example, with increased SRT during ASR treatment, the amount of SMP decreases, but the reactivity and aromaticity of SMPs also increases. Similarly, longer SRT generates more high molecular weight compounds (>10,000 Da). Accordingly, if the nature and levels of these compounds vary so much depending on ASR operation, it is possible that DOA removal efficiency might have been affected by WWTP operation in ways that may not necessarily correlate with the measured fluorophore components. 


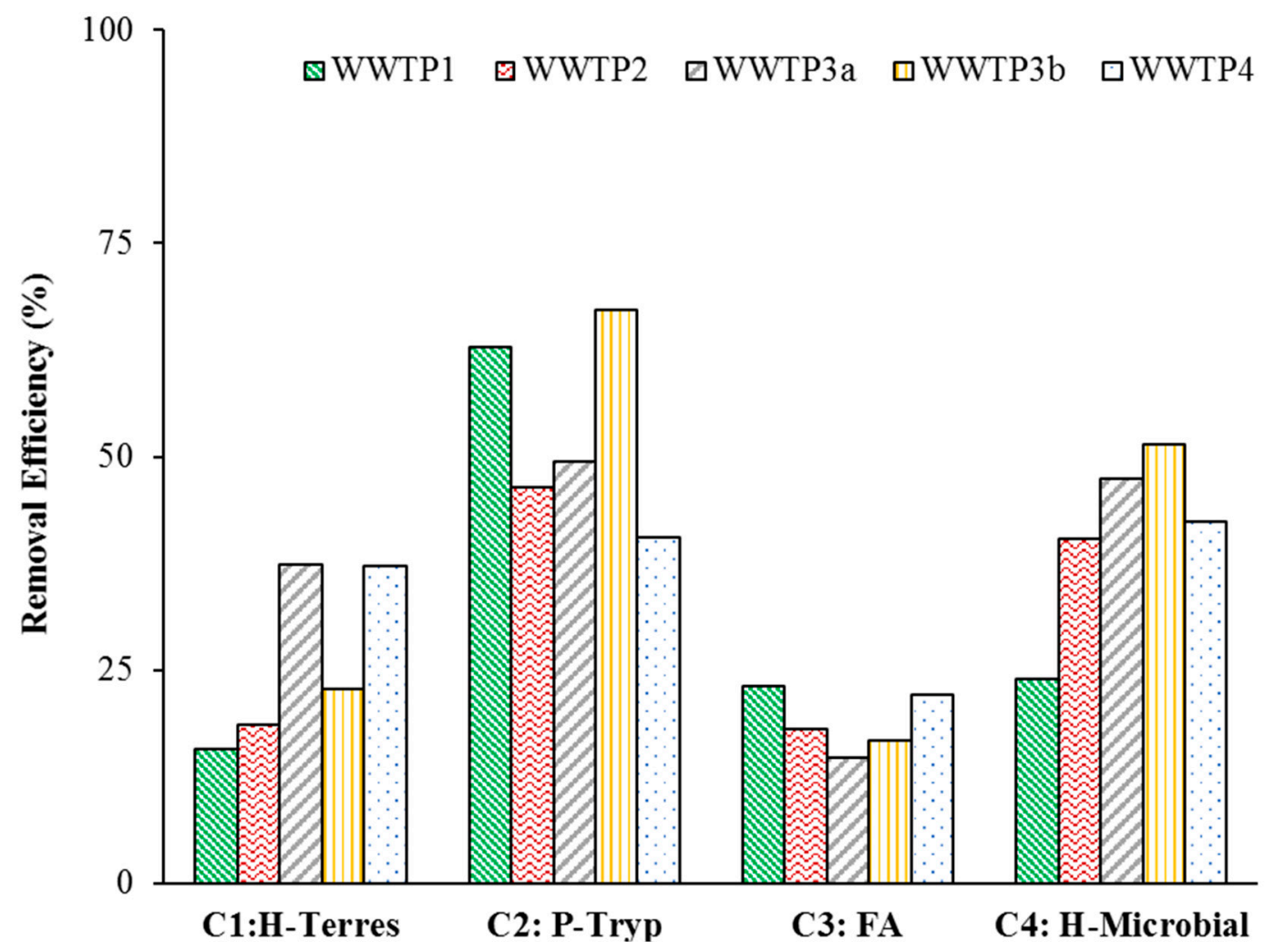

Figure 3. The removal efficiency (\%) of fluorescence excitation-emission (F-EEM) components derived from EEM datasets in the studied WWTPs. C1: H-Terres (humic acid-like terrestrial); C2: P-Tryp (protein-tryptophan), C3: FA (Fulvic Acid-like), C4: H-microbial.

Table 2. Pearson correlation coefficients ( $r$ ) and associated significance level between the removal efficiencies of different F-EEM indexes in the investigated WWTPs $(n=40)$.

\begin{tabular}{ccccccccc}
\hline F-EEM Indexes & P2 & FA & SMP & HA & C1 & C2 & C3 & C4 \\
\hline P1 & $0.544^{* *}$ & 0.262 & 0.060 & -0.146 & $-0.326^{*}$ & -0.020 & $-0.469^{* *}$ & -0.212 \\
P2 & - & 0.010 & -0.019 & -0.101 & 0.090 & -0.034 & -0.239 & 0.130 \\
FA & - & - & 0.133 & 0.258 & 0.088 & -0.059 & 0.153 & -0.011 \\
SMP & - & - & - & -0.035 & -0.204 & -0.033 & -0.083 & -0.098 \\
HA & - & - & - & - & 0.081 & 0.199 & -0.217 & -0.053 \\
C1 & - & - & - & - & - & $0.315^{*}$ & $0.749^{* *}$ & $0.597^{* *}$ \\
C2 & - & - & - & - & - & - & $0.402^{*}$ & $0.611^{* *}$ \\
C3 & - & - & - & - & - & - & - & $0.609^{* *}$ \\
\hline
\end{tabular}

${ }^{*}$ Correlation is significant at the 0.05 level (2-tailed); ${ }^{* *}$ correlation is significant at the 0.01 level (2-tailed).

\subsection{Targeted Drugs Removal during Wastewater Treatment}

All the compounds (DOA) were detectable in influent and effluent wastewater samples ranging from a few ng/L to $\mu \mathrm{g} / \mathrm{L}$. Codeine and METH had the highest concentrations of all the examined drugs in all WWTPs. Concentration profiles of all the DOA are reported in Figure 4 and presented as the average of four WWTPs during the sampling period ( 4 months $\times 7$ days $=28$ samples $/$ WWTP). There was a significant decrease in the concentrations of all the targeted DOA in effluent samples after the treatment processes; however, their presence in effluents proves they are only partially eliminated during the wastewater treatment process. Thus, the removal rate of targeted DOA was estimated by evaluating the relative concentration in effluent versus influent wastewater. 


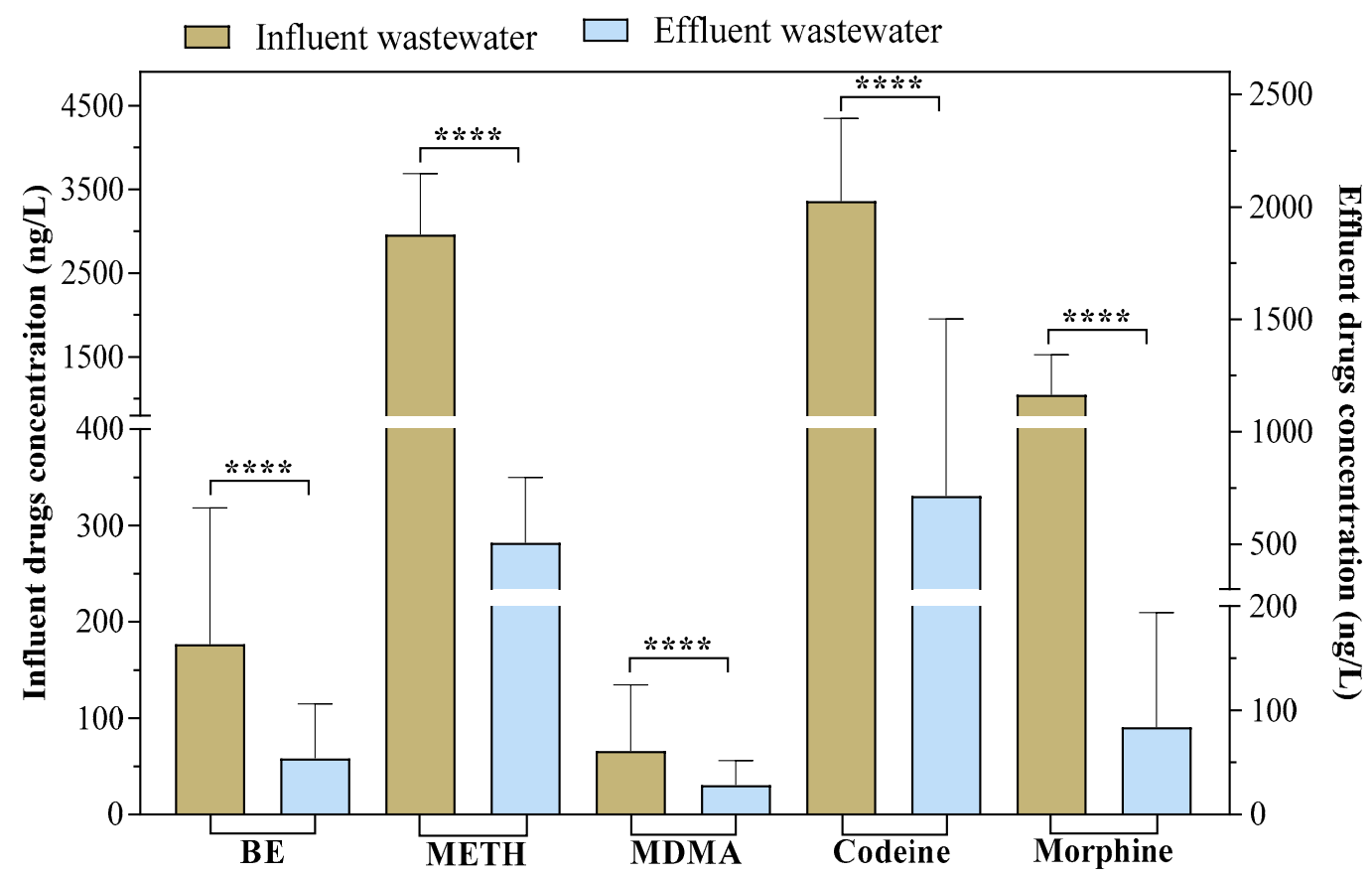

Figure 4. Targeted drugs average concentration profiles in influent and effluent wastewater samples collected from each WWTP during the study period. The concentrations are presented as mean \pm SD where $\mathrm{n}=112$ for influent and $\mathrm{n}=140$ for effluent samples. Asterisks represent statistically significant differences between influent and effluent concentrations (significance level of 2-tailed $t$-test where: $* * * *=p<001)$.

Varying removal efficiencies were observed for the DOA in the WWTPs depending on the secondary treatment process and physical-chemical properties of drugs [13]. For example, differences in removal efficiency were observed for BE (91\% vs. $28 \%$ ) and MDMA ( $40 \%$ vs. $30 \%)$ in WWTP1 and WWTP2, respectively, operating with two different secondary treatment processes. Figure 5 summarises the removal efficiencies (mean \pm SD) of the DOA with respect to WWTP during the sampling period. The variation in removal efficiency can be associated with several factors, including WWTP operational conditions (hydraulic or sludge retention time), influent load or drugs type $[13,32,33]$. A relationship was determined between removal efficiencies and DOA load, and it was found that BE, METH and codeine removal was significantly correlated with their respective drug loads $(p<0.01)$.

In this study, METH and morphine were removed most effectively (average $\approx 90 \%$ ). BE removal was $>80 \%$ in all WWTPs except for WWTP2, which also showed an overall low performance for all DOA and dissolved organic carbon. MDMA showed highly diverse removal rates (30-90\%) among WWTPs as well as within the WWTP. Codeine was almost completely removed by WWTP3 and WWTP4, but less than 50\% average removal efficiency was achieved by WWTP1 and WWTP2. 


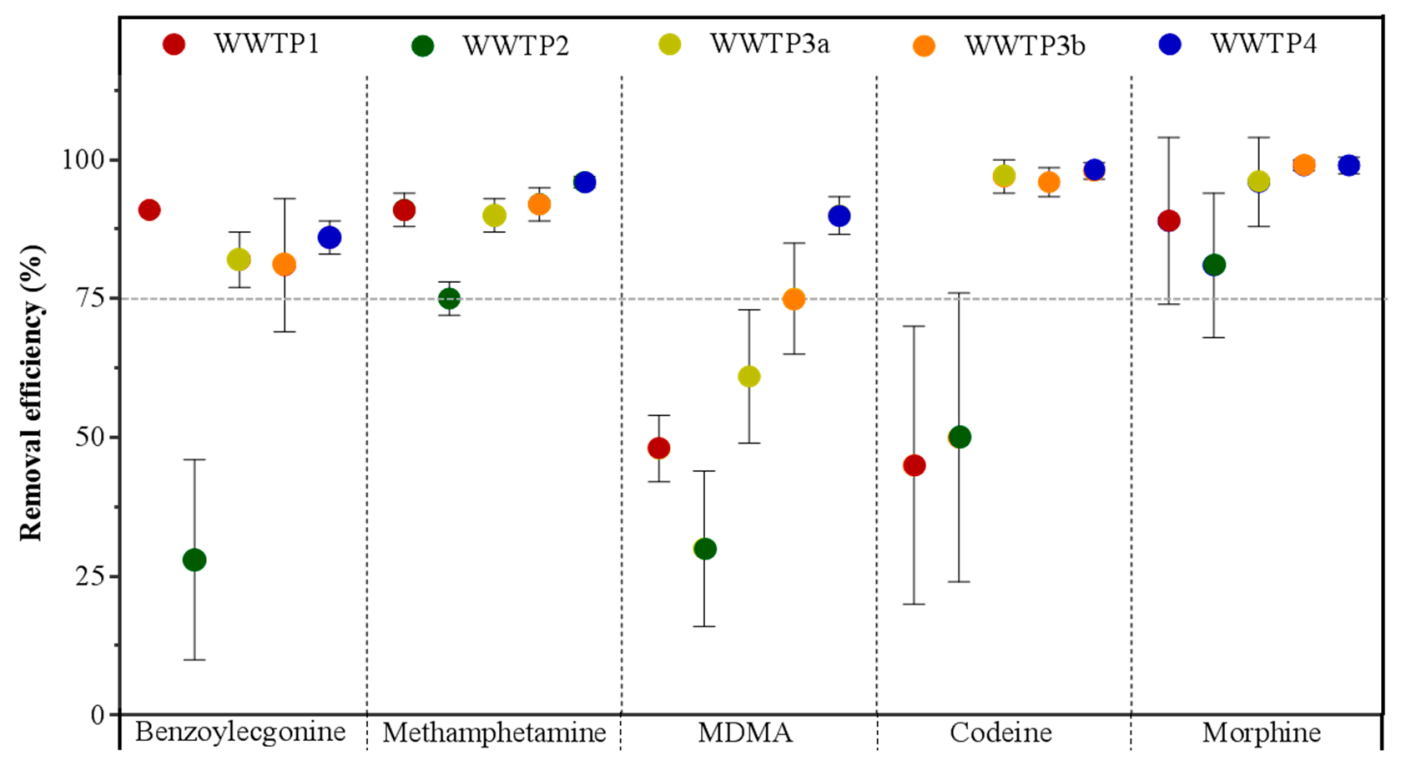

Figure 5. Removal efficiencies for the targeted drugs (mean $\pm \mathrm{SD}$ ) during the sampling duration at each of the four WWTPs.

\subsection{Relationship between DOA Removal and F-EEM Regions}

To determine the relationship between the targeted DOA removal and F-EEM indexes (PARAFAC components and FRI regions), a Pearson correlation analysis was carried out. The results are summarised in Table 3, and a correlation was examined for BE, METH and codeine removal with F-EEM regions. A significant negative relationship was observed between proteinaceous related regions (aromatic proteins, tyrosine and tryptophan-like substances) with BE and METH removal efficiency, while a significant positive relationship was seen with codeine removal. The results from this study show that the removal efficiency of BE and METH decreases with an increase in protein-like substances, and the possible reason for this might be their protein binding properties. Both compounds (BE and METH) have a low binding affinity with protein [34,35], and this could be the reason for their negative relationship with their removal efficiency. Alternatively, protein binding of codeine is higher $(\approx 30 \%)$ compared to BE and METH [36]; therefore, component $\mathrm{C} 2$ related to tryptophan-like substances was positively correlated with codeine removal. Regarding MDMA and morphine, no significant correlations were observed with any of the F-EEM regions.

Table 3. Summary of the Pearson correlation analysis between drug removal and F-EEM indices.

\begin{tabular}{cccc}
\hline Compounds & F-EEM correlated regions & Pearson coefficient (r) & $p$-value \\
\hline \multirow{2}{*}{ Benzoylecgonine } & P1 & -0.407 & $0.009^{* *}$ \\
& P2 & -0.329 & $0.038^{*}$ \\
Pethamphetamine & P2 & -0.324 & $0.041^{*}$ \\
& SMP & -0.436 & $0.005^{* *}$ \\
Codeine & HA & -0.401 & $0.010^{*}$ \\
& C2 & 0.329 & $0.038^{*}$ \\
& FA & 0.433 & $0.005^{* *}$ \\
\hline
\end{tabular}

* Denotes correlation is significant at the 0.05 level (2-tailed); ${ }^{* *}$ denotes correlation is significant at the 0.01 level (2-tailed).

Regarding organic regions (humic and fulvic), METH was correlated with HA ( $p=0.038$ ) and codeine with FA $(p=0.019)$ FRI regions. It is not clear at present what the reason was for the positive relationship between HA and METH removal, while the relationship was negative between FA and codeine removal, but we can postulate that it may be associated with the compounds' physio-chemical 
properties. No correlation was observed between DOA removal and PARAFAC components except for $\mathrm{C} 2$ with codeine removal. The findings obtained from this study lead to the conclusion that there was some relationship between DOA removal and protein regions, but relatively little for humic/fulvic-like substances. Thus, follow up research should consider investigating different water matrices and study relationships between drugs at controlled concentrations and fluorescence spectra.

\section{Conclusions}

In this study, wastewater samples collected from different WWTPs were analysed to find the possibility of using fluorescence spectroscopy to monitor DOA. The fluorescence data were analysed by different methods (PARAFAC and FRI), and a positive relation was observed between the same regions, while negative relation was observed between different regions. The DOA with higher estimated removals (METH and codeine) were correlated well with fluorescence indexes related to proteinaceous substances. However, no correlation was observed with PARAFAC components; this could be due to less identified components during the PARAFAC modelling. Overall, this study provides a first assessment of the feasibility of using fluorescence spectroscopy for the monitoring of DOA in relation to their removal in WWTPs.

Supplementary Materials: The following are available online at http:/ /www.mdpi.com/2073-4441/11/2/377/s1, Table S1: Characteristics of wastewater treatment plants selected for the study, Table S2: Average dissolved organic carbon concentration in influent and effluent samples during the study period \pm standard deviation, Figure S1: Visual example of fluorescence EEM's of the influent and effluent of WWTP1 and WWPT4.

Author Contributions: Conceptualization, M.K.Y., R.A. and C.P.S.; formal analysis, M.K.Y.; funding acquisition, M.K.Y., M.D.S. and C.P.S.; investigation, M.K.Y.; methodology, M.K.Y.; project administration, M.K.Y., R.A., M.D.S. and C.P.S.; resources, M.K.Y.; supervision, R.A., M.D.S. and C.P.S.; visualization, M.K.Y.; writing-original draft, M.K.Y.; writing — review and editing, M.K.Y., R.A., M.D.S. and C.P.S.

Funding: This research was supported by an Australian Government Research Training Program (RTP) Scholarship. This research received no external funding.

Acknowledgments: The authors gratefully acknowledge SA Water Corporation and Allwater staff for their assistance in sample collection. The authors would also like to thank Dr. John Awad for his valuable support in PARAFAC and FRI modelling.

Conflicts of Interest: The authors declare no conflict of interest.

\section{References}

1. Castiglioni, S.; Zuccato, E.; Chiabrando, C.; Fanelli, R.; Bagnati, R. Mass spectrometric analysis of illicit drugs in wastewater and surface water. Mass Spectrom. Rev. 2008, 27, 378-394. [CrossRef] [PubMed]

2. Castrignanò, E.; Yang, Z.; Bade, R.; Baz-Lomba, J.A.; Castiglioni, S.; Causanilles, A.; Covaci, A.; Gracia-Lor, E.; Hernandez, F.; Kinyua, J.; et al. Enantiomeric profiling of chiral illicit drugs in a pan-european study. Water Res. 2018, 130, 151-160. [CrossRef] [PubMed]

3. Wang, D.-G.; Zheng, Q.-D.; Wang, X.-P.; Du, J.; Tian, C.-G.; Wang, Z.; Ge, L.-K. Illicit drugs and their metabolites in 36 rivers that drain into the bohai sea and north yellow sea, north china. Environ. Sci. Pollut. Res. 2016, 23, 16495-16503. [CrossRef] [PubMed]

4. Yadav, M.K.; Short, M.D.; Aryal, R.; Gerber, C.; van den Akker, B.; Saint, C.P. Occurrence of illicit drugs in water and wastewater and their removal during wastewater treatment. Water Res. 2017, 124, 713-727. [CrossRef] [PubMed]

5. Gruchlik, Y.; Linge, K.; Joll, C. Removal of organic micropollutants in waste stabilisation ponds: A review. J. Environ. Manag. 2018, 206, 202-214. [CrossRef] [PubMed]

6. Richmond, E.K.; Rosi, E.J.; Walters, D.M.; Fick, J.; Hamilton, S.K.; Brodin, T.; Sundelin, A.; Grace, M.R. A diverse suite of pharmaceuticals contaminates stream and riparian food webs. Nat. Commun. 2018, 9, 4491. [CrossRef] [PubMed]

7. Li, W.-T.; Chen, S.-Y.; Xu, Z.-X.; Li, Y.; Shuang, C.-D.; Li, A.-M. Characterization of dissolved organic matter in municipal wastewater using fluorescence parafac analysis and chromatography multi-excitation/emission scan: A comparative study. Environ. Sci. Technol. 2014, 48, 2603-2609. [CrossRef] [PubMed] 
8. Sgroi, M.; Roccaro, P.; Korshin, G.V.; Greco, V.; Sciuto, S.; Anumol, T.; Snyder, S.A.; Vagliasindi, F.G.A. Use of fluorescence eem to monitor the removal of emerging contaminants in full scale wastewater treatment plants. J. Hazard. Mater. 2017, 323, 367-376. [CrossRef]

9. Aryal, R.; Yadav, M.; Hussain, S.; Beecham, S.; Diprose, D. Tracking changes in fluorescent organic composition in leachates using excitation emission matrix-parallel factor analysis. Process Saf. Environ. Prot. 2016, 104, 507-516. [CrossRef]

10. Aryal, R.; Lee, B.-K.; Beecham, S.; Kandasamy, J.; Aryal, N.; Parajuli, K. Characterisation of road dust organic matter as a function of particle size: A parafac approach. Waterairsoil Pollut. 2015, 226, 1-10. [CrossRef]

11. Murphy, K.R.; Stedmon, C.A.; Graeber, D.; Bro, R. Fluorescence spectroscopy and multi-way techniques. Parafac. Anal. Methods 2013, 5, 6557-6566. [CrossRef]

12. Chen, W.; Westerhoff, P.; Leenheer, J.A.; Booksh, K. Fluorescence excitation-emission matrix regional integration to quantify spectra for dissolved organic matter. Environ. Sci. Technol. 2003, 37, 5701-5710. [CrossRef] [PubMed]

13. Yadav, M.K.; Short, M.D.; Gerber, C.; van den Akker, B.; Aryal, R.; Saint, C.P. Occurrence, removal and environmental risk of markers of five drugs of abuse in urban wastewater systems in south australia. Environ. Sci. Pollut. Res. 2018. [CrossRef] [PubMed]

14. Irvine, R.J.; Kostakis, C.; Felgate, P.D.; Jaehne, E.J.; Chen, C.; White, J.M. Population drug use in australia: A wastewater analysis. Forensic Sci. Int. 2011, 210, 69-73. [CrossRef] [PubMed]

15. Andersson, C.A.; Bro, R. The n-way toolbox for matlab. Chemom. Intell. Lab. Syst. 2000, 52, 1-4. [CrossRef]

16. Yamashita, Y.; Jaffé, R.; Maie, N.; Tanoue, E. Assessing the dynamics of dissolved organic matter (dom) in coastal environments by excitation emission matrix fluorescence and parallel factor analysis (eem-parafac). Limnol. Oceanogr. 2008, 53, 1900-1908. [CrossRef]

17. Butturini, A.; Ejarque, E. Dissolved organic matter fluorescence a finite mixture approach to deconvolve excitation-emission matrices. Biogeosciences 2013, 10, 5875-5887. [CrossRef]

18. Santos, C.H.; Nicolodelli, G.; Romano, R.A.; Tadini, A.M.; Villas-Boas, P.R.; Montes, C.R.; Mounier, S.; Milori, D.M. Structure of humic substances from some regions of the amazon assessed coupling $3 \mathrm{~d}$ fluorescence spectroscopy and cp/parafac. J. Braz. Chem. Soc. 2015, 26, 1136-1142. [CrossRef]

19. Fukuzaki, K.; Imai, I.; Fukushima, K.; Ishii, K.-I.; Sawayama, S.; Yoshioka, T. Fluorescent characteristics of dissolved organic matter produced by bloom-forming coastal phytoplankton. J. Plankton Res. 2014, 36, 685-694. [CrossRef]

20. Hudson, N.; Baker, A.; Reynolds, D. Fluorescence analysis of dissolved organic matter in natural, waste and polluted waters-A review. River Res. Appl. 2007, 23, 631-649. [CrossRef]

21. Wei, J.; Han, L.; Song, J.; Chen, M. Evaluation of the interactions between water extractable soil organic matter and metal cations (cu(ii), eu(iii)) using excitation-emission matrix combined with parallel factor analysis. Int. J. Mol. Sci. 2015, 16, 14464-14476. [CrossRef] [PubMed]

22. Murphy, K.R.; Hambly, A.; Singh, S.; Henderson, R.K.; Baker, A.; Stuetz, R.; Khan, S.J. Organic matter fluorescence in municipal water recycling schemes: Toward a unified parafac model. Environ. Sci. Technol. 2011, 45, 2909-2916. [CrossRef] [PubMed]

23. Mostofa, K.M.; Yoshioka, T.; Konohira, E.; Tanoue, E.; Hayakawa, K.; Takahashi, M. Three-dimensional fluorescence as a tool for investigating the dynamics of dissolved organic matter in the lake biwa watershed. Limnology 2005, 6, 101-115. [CrossRef]

24. Ghervase, L.; Ioja, C.; Carstea, E.; Niculita, L.; Savastru, D.; Pavelescu, G.; Vanau, G. Evaluation of lentic ecosystems from bucharest city. Int. J. Energy Environ. 2011, 5, 183-192.

25. Goslan, E.H.; Voros, S.; Banks, J.; Wilson, D.; Hillis, P.; Campbell, A.T.; Parsons, S.A. A model for predicting dissolved organic carbon distribution in a reservoir water using fluorescence spectroscopy. Water Res. 2004, 38, 783-791. [CrossRef] [PubMed]

26. Coble, P.G. Characterization of marine and terrestrial dom in seawater using excitation-emission matrix spectroscopy. Mar. Chem. 1996, 51, 325-346. [CrossRef]

27. Mostofa, K.M.G.; Wu, F.; Liu, C.-Q.; Fang, W.L.; Yuan, J.; Ying, W.L.; Wen, L.; Yi, M. Characterization of nanming river (southwestern china) sewerage-impacted pollution using an excitation-emission matrix and parafac. Limnology 2010, 11, 217-231. [CrossRef] 
28. Watanabe, A.; Moroi, K.; Sato, H.; Tsutsuki, K.; Maie, N.; Melling, L.; Jaffé, R. Contributions of humic substances to the dissolved organic carbon pool in wetlands from different climates. Chemosphere 2012, 88, 1265-1268. [CrossRef] [PubMed]

29. Westgate, P.J. Characterization of proteins in effluents from three wastewater treatment plants that discharge to the connecticut river. Environ. Water Resour. Eng. Masters Proj. 2009, 42. [CrossRef]

30. Westgate, P.J.; Park, C. Evaluation of proteins and organic nitrogen in wastewater treatment effluents. Environ. Sci. Technol. 2010, 44, 5352-5357. [CrossRef] [PubMed]

31. Yu, H.; Qu, F.; Sun, L.; Liang, H.; Han, Z.; Chang, H.; Shao, S.; Li, G. Relationship between soluble microbial products (smp) and effluent organic matter (efom): Characterized by fluorescence excitation emission matrix coupled with parallel factor analysis. Chemosphere 2015, 121, 101-109. [CrossRef] [PubMed]

32. Gros, M.; Petrović, M.; Ginebreda, A.; Barceló, D. Removal of pharmaceuticals during wastewater treatment and environmental risk assessment using hazard indexes. Environ. Int. 2010, 36, 15-26. [CrossRef] [PubMed]

33. Kim, S.; Thiessen, P.A.; Bolton, E.E.; Chen, J.; Fu, G.; Gindulyte, A.; Han, L.; He, J.; He, S.; Shoemaker, B.A.; et al. Pubchem substance and compound databases. Nucleic Acids Res. 2016, 44, D1202-D1213. [CrossRef] [PubMed]

34. Borges, C.R. Roles of Drug Basicity, Melanin binding, and Cellular Transport in Drug Incorporation into Hair; Dept. of Pharmacology and Toxicology, University of Utah: Salt Lake City, UT, USA, 2001.

35. Huestis, M.A.; Cone, E.J. Methamphetamine disposition in oral fluid, plasma, and urine. Ann. N. Y. Acad. Sci. 2007, 104-121. [CrossRef] [PubMed]

36. Mohammed, S.S.; Christopher, M.M.; Mehta, P.; Kedar, A.; Gross, S.; Derendorf, H. Increased erythrocyte and protein binding of codeine in patients with sickle cell disease. J. Pharm. Sci. 1993, 82, 1112-1117. [CrossRef] [PubMed]

(C) 2019 by the authors. Licensee MDPI, Basel, Switzerland. This article is an open access article distributed under the terms and conditions of the Creative Commons Attribution (CC BY) license (http://creativecommons.org/licenses/by/4.0/). 